\title{
A fossilized marble run: the peculiar taphonomy of Ordovician diploporitan blastozoans from Sweden
}

\author{
Christian Klug ${ }^{1}$ (1) $\cdot$ Alexander Pohle ${ }^{1} \cdot$ Steffen Kiel ${ }^{2} \cdot$ Björn Kröger $^{3}$
}

Received: 11 September 2018 / Accepted: 20 October 2018/Published online: 3 November 2018

(C) Akademie der Naturwissenschaften Schweiz (SCNAT) 2018

\begin{abstract}
Diploporitans had subspherical thecae, which usually were attached to hard substrates either directly with an attachment disc at the base of their theca or with a stem and holdfast. After the death of the animal, isolated thecae were easily transported by currents over more or less consolidated sediment. We describe a case where 13 diploporitan thecae were trapped in the remains of a cephalopod with an orthoconic conch. Most of the thecae show a perfect fit and are size-sorted within the conch or siphuncle. We discuss the taphonomic processes that might have been involved in this rare kind of alignment and sorting.
\end{abstract}

Keywords Diploporita $\cdot$ Rhombifera $\cdot$ Endocerida $\cdot$ Ordovician $\cdot$ Taphonomy $\cdot$ Alignment

\section{Introduction}

Representatives of the Diploporita and Rhombifera (Blastozoa) occur in rock-forming numbers in several outcrops across Baltoscandia (e.g. Regnell 1960). According to their locally high abundance, representatives of genera such as Echinosphaerites and Sphaeronites likely lived in densely populated meadows (e.g. Lindskog and Eriksson 2017). Their more or less spherical thecae, which consisted of lightly built thecal plates but with very rigid sutures, had feeding appendages with a mineralized skeleton, which very quickly disarticulated after death, and thus, their thecae were, depending on sediment consistency, easily transported post-mortem over the seafloor by water currents or waves. Due to their shape, the most common mode of transport was probably rolling, providing the attachment and the brachioles broke off. Rolling transport has been

Editorial Handling: D. Marty.

Christian Klug

chklug@pim.uzh.ch

1 Paläontologisches Institut und Museum, Karl Schmid-Strasse 4, 8006 Zurich, Switzerland

2 Department of Palaeobiology, Swedish Museum of Natural History, P. O. Box 50007, 10405 Stockholm, Sweden

3 Finnish Museum of Natural History, University of Helsinki, P. O. Box 44, Jyrängöntie 2, 00014 Helsinki, Finland documented for a variety of organisms on land (e.g. tumbleweed; Ganong 1921; Becker 1978) and in water (e.g. ammonoids; Rothpletz 1909; Seilacher 1963, 1971; Maeda and Seilacher 1996). Although rolling transport of subspherical diploporitan thecae is a likely phenomenon, it has not yet been discussed as far as we know.

Here, we present the case of a cephalopod specimen, where the corroded remains of an orthoconic cephalopod served as a fossil trap for diploporitans. The specimen was historically collected from the Middle Ordovician Holen limestone at Råbäck Kalkbott, Kinnekulle table mountain, Västergotland, southern Sweden (Fig. 1). We discuss the possible taphonomic processes that can explain the mode of alignment of the diploporitans in the conch.

\section{Material}

Specimen NRM Ec34704 is a 332-mm-long poorly preserved fragment of an orthoconic cephalopod; its apertural diameter is $19 \mathrm{~mm}$ and adapically it measures $8 \mathrm{~mm}$ (Fig. 2). It contains at least 13 subsphaerical thecae of diploporitans ranging between ca. 12 and $19 \mathrm{~mm}$ in diameter. From the aperture towards the apex, the diameters (in millimetres) of the diploporitan thecae are as follows:

$$
\begin{aligned}
& 19-19-12-19-12-15-17-18-16-17 \\
& -(24 \text { mm gap without theca })-15-15-13
\end{aligned}
$$




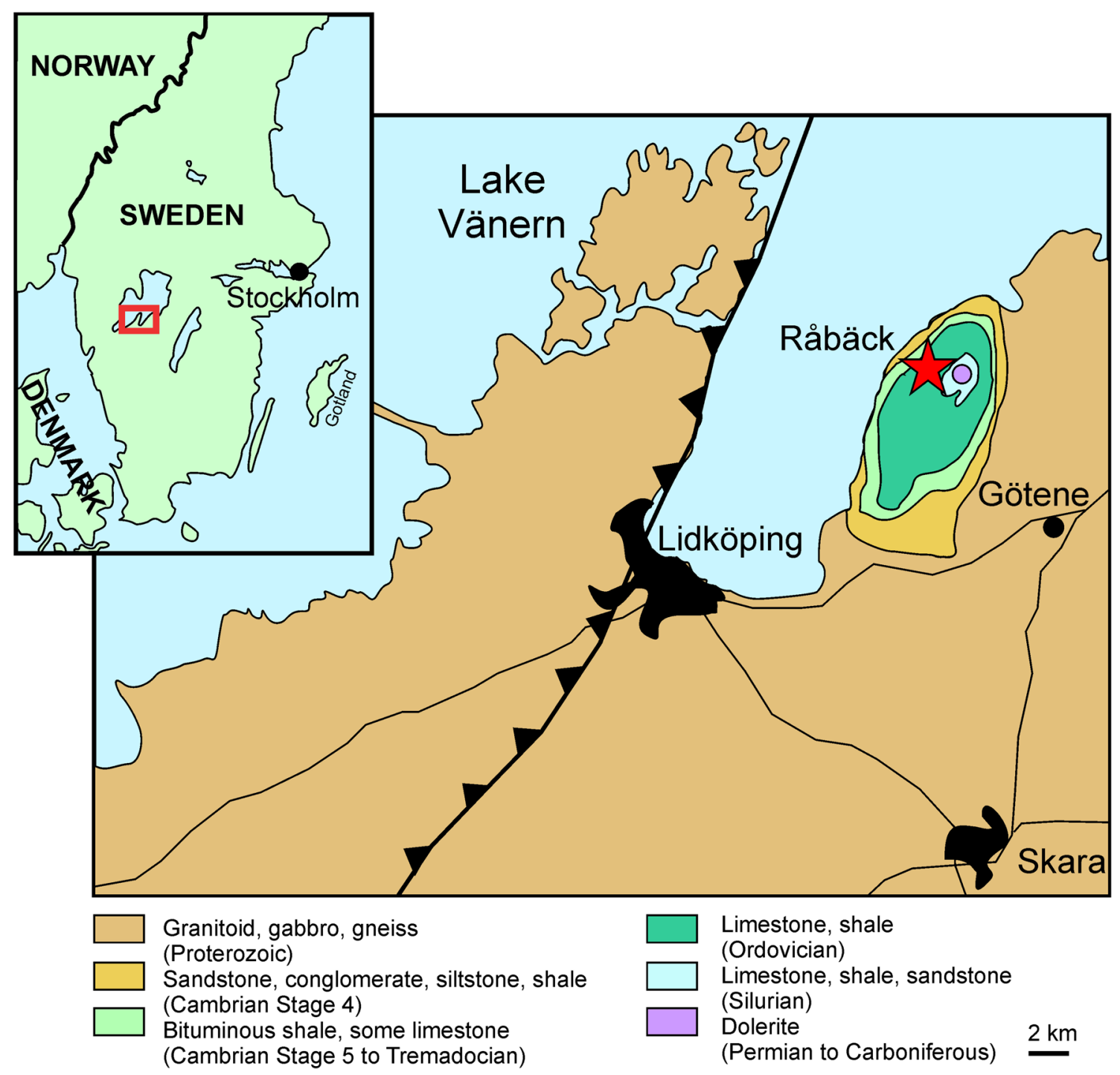

Fig. 1 Geological map of Västergötland with the locality where the specimen described herein was collected Modified after Calner et al. (2013)

The average ratio between conch diameter and diploporitan diameter is 1.14 , i.e. most of the diploporitans touch the shell.

The specimen is labelled as collected from Råbäck Kalkbott (the latter word meaning quarry). The quarry does not exist anymore, but probably the label refers to one of the old quarries east of the village Råbäck on the western side of the Kinnekulle mountain, c. 10-12 km southwest of Hällekis, Västergotland, southern Sweden. The label also states: "övre röd Orthocerkalk" (upper Red Orthoceras limestone), which roughly corresponds to the Holen Limestone in this area. However, the limestone of the specimen itself is green. The only green bed in the upper Red Orthoceras limestone exposed on the western side of the Kinnekulle is the "Täljsten interval", which locally is also very rich in Sphaeronites (Eriksson et al. 2012;
Lindskog and Eriksson 2017). Hence, the age of the specimen can be constrained as Lenodus variabilisYangtzeplatognathus crassus condodont zone of the Kunda regional stage, Darriwilian, Middle Ordovician (see Lindskog and Eriksson 2017 and references therein).

The specimen is stored at the Swedish Museum of Natural History in Stockholm (NRM Ec34704).

\section{Taxonomy}

The cephalopod is an internal mould of an orthoconic conch or of a large siphuncle of an orthocone, which has a slightly undulating lower and lateral surface (Fig. 2C). It is unclear whether some of this undulation is primary or due to compaction processes of the marly sediment, also linked to the presence of the diploporitans inside it. It is possible that the specimen is actually an internal mould or even a 


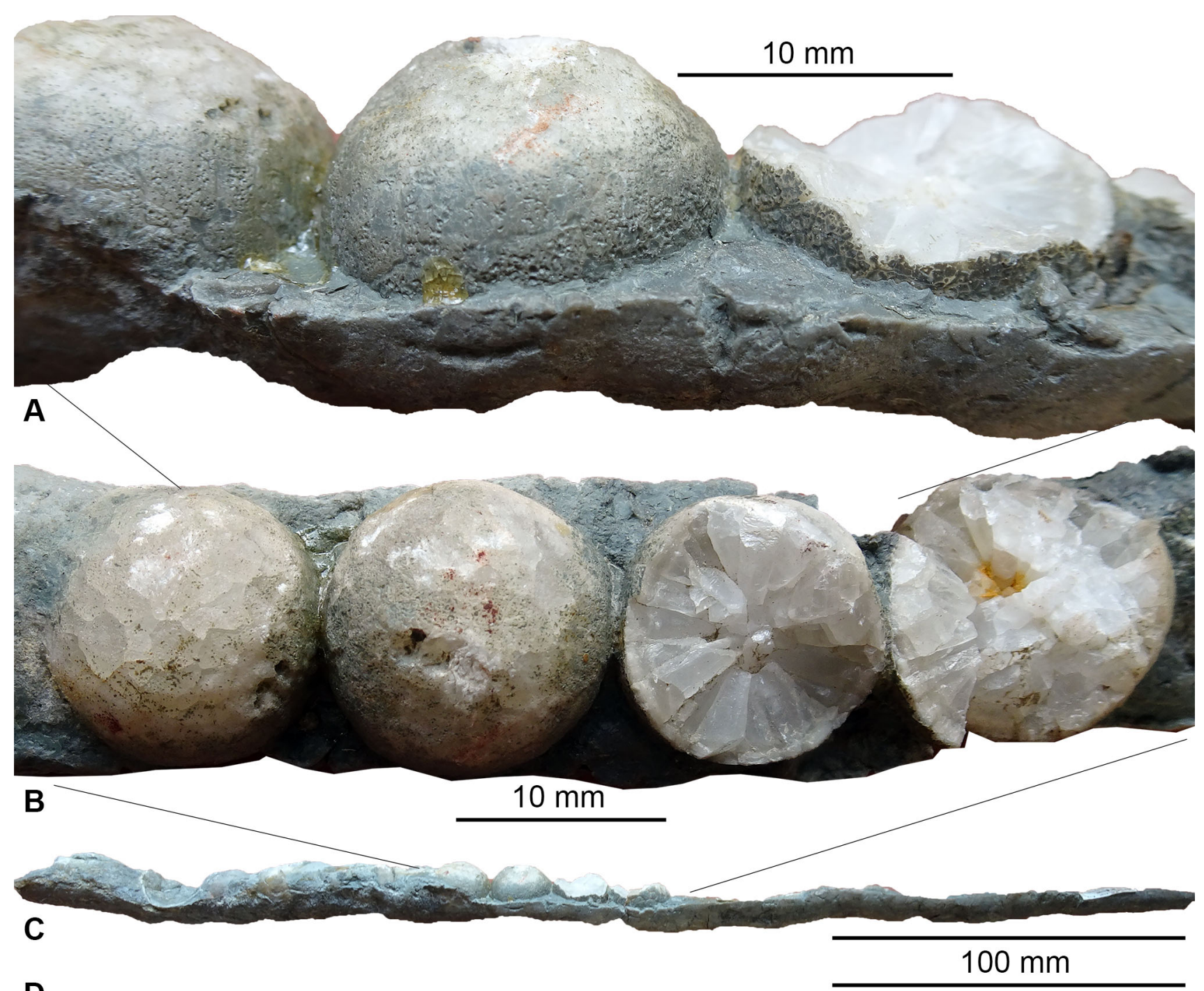

D

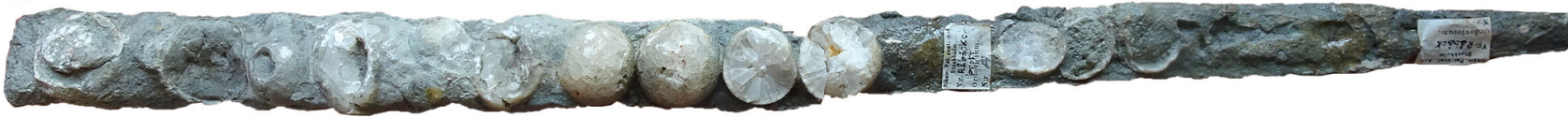

Fig. 2 Orthoconic conch or siphuncle of a cephalopod (?Proterovaginoceras sp.) filled with diploporitans from the Ordovician (Darriwillian, Kunda stage, Holen limestone, upper Red Orthoceras Limestone) of Råbäcks in Västergötland province (Sweden); NRM Ec34704. A Detail of the specimen showing three thecae of Sphaeronites (Sphaeronites) sp.; note the pores and plate boundaries on the surface; the former sediment surface corresponds to the midline of the sedimentary filling of the cephalopod conch or

secondary infilling of an external mould of an endocerid siphuncle, which shows similar undulations (compare, e.g. Flower 1955; Balashov 1968; Kröger 2012). Only about one half of the internal mould is preserved and the presence of the diploporitans in much of the conch evidences corrosion of the other half of the conch prior to its burial; we cannot think of a natural process that could make a longiconic conch break in half (see also discussion in Paul siphuncle. Also note the darker colour of surface towards the bottom, probably caused by the darker sediment of the geopetal filling. B Detail showing four diploporitans, seen from above; the two diploporitans on the right are broken in the middle, revealing the syntaxial sparite fillings of the former void inside the theca. The entire specimen seen from the side $(\mathbf{C})$ and from the top (D), i.e. looking down on the sediment surface

and Bockelie 1983). No traces of the shell, siphuncle or septa are discernible, making a systematic assignment nearly impossible, although the likelihood that it was an endocerid is very high.

The Kunda Stage of Baltoscandia is well-known for its abundant cephalopods (e.g. Calner et al. 2013; Kröger 2012; Kröger and Rasmussen 2014; Kröger and Zhang 2009). However, the historical name "Orthoceratite" 
limestone is misleading at least for the Holen limestone part, which historically also was more correctly named "Vaginatum limestone", the latter referring to its most abundant cephalopod taxon, Proterovaginoceras incognitum (Kröger 2012; Kröger and Rasmussen 2014). Generally, slender, large, smooth endocerids are most common in the limestones of the Kunda regional stage across Baltoscandia. Probably, the specimen described herein is a poorly preserved fragment of a large isolated siphuncle of Proterovaginoceras.

As far as the diploporitans are concerned, some species occur in great numbers in the Middle Ordovician of Baltoscandia including the diploporitans Sphaeronites pomum Gyllenhaal, 1772 and S. minor Paul \& Bockelie, 1983 as well as the rhombiferan Echinosphaerites aurantium (Gyllenhaal, 1772). For the Holen Kalksten of southern Sweden, Calner et al. (2013) reported abundant S. pomum, although overall, Echinosphaerites might be more abundant in the Baltoscandian Ordovician.

Unfortunately, the key characters of the different genera or species are not preserved. According to J. Waters (personal communication, October 2018), the presence of respiratory pores with no organization in the plates, the unorganized plating, some small tubercles as thecal ornamentation between the respiratory structures, and the polygonal peripores (rather densely packed) with a thin tubercle in the middle and thin rims strongly suggest that they belong to Sphaeronites (Sphaeronites) Paul, 1973. At species level, determination is more difficult. S. (S.) pomum is usually larger than the thecae in specimen NRM Ec34704, it has rounded peripores with tubercles on their rims (their absence might be a taphonomic problem, though). Sphaeronites (S.) minor corresponds well with the size of the specimens; it has rounded to polygonal peripores with a flattened to slightly convex bottom (no central tubercles) and also some tubercles on their rims. Therefore, most of the characters (available on the specimens) would suggest that these blastozoans belong to $S$. (S.) minor. Nevertheless, although both species were reported from the locality, most authors reported $S$. (S.) pomum. Furthermore, size is probably a poor character here, because the small size of the specimens is possibly linked with the sorting process that occurred in the orthocone. We thus refer to the blastozoans in open nomenclature: Sphaeronites (Sphaeronites) sp.

\section{Taphonomy}

The cephalopod remains were only partially filled by sediment, in most cases below the middle of the conch. The phenomenon of roughly half-filled orthocones was mentioned as being very common in the host strata by Paul and Bockelie (1983: fig. 8). They also pointed out that the siphuncle often lies at the bottom (in endocerids) due to its massive endosiphonal structures (endocones). Furthermore, they report that many specimens of orthocones were reworked as evidenced by pre-fossilized ones that were only partially filled but lying with the convex side up. Additionally, some specimens were "truncated against discontinuity surfaces" (Paul and Bockelie 1983: p. 695) or current-aligned.

Since most diploporitan thecae fit almost perfectly into the cephalopod conch, the level of the sediment surrounding the cephalopod remains probably corresponds approximately to the level to which the conch was missing, either by corrosion or a combination of processes. Consequently, it represents some kind of geopetal structure, indicating the former position of the fossils in the sediment. This is corroborated by the geopetal structures in the diploporitans; those thecae that are intact and the three broken ones show the calcite crystals that syntaxially grew inwards from the thecal plates (e.g. Fraas 1887; Neugebauer 1978, 1979a, b; Paul and Bockelie 1983; Walker et al. 1999; Klug 1992; Vollbrecht 2015). Remarkably, the Ordovician was the time with the most abundant syntaxial overgrowths on echinoderms (Walker et al. 1999: fig. 4), which appears to be linked with the prevailing calcite sea conditions.

The two smallest diploporitans that lie in the most apical part of the cephalopod conch show an even sediment-filling containing bioclasts of up to millimetre-size. The surface of this filling corresponds in level to that of the cephalopod conch; thus, these thecae were probably already broken prior to burial, thereby allowing coarser sediment particles to enter the thecae. The two diploporitans lying in the most apertural part are also broken, but it is unclear at which stage of taphonomy.

As mentioned by Paul and Bockelie (1983: p. 694f), the sediments show several indications for currents such as aligned orthonic cephalopod conchs (see also, e.g. Grahn 1986; Wendt 1995 and references therein). Both empty cephalopod conchs and the lightly built (stereome structure of sclerites) empty thecae of diploporitans were easily carried even by weak bottom currents. While the orthocones were possibly initially current aligned, the diploporitan thecae were likely rolling in any direction and do not allow a reconstruction of palaeocurrents. In the case described here, 13 thecae of slightly varying size were trapped in a half of a cephalopod conch or siphuncle. The slight size sorting along the length of the cephalopod conch and the excellent fit of most of the diploporitans with the conch's width suggest that the size of the diploporitans relative to the conch was crucial for whether they stayed in the conch or rolled on.

The stratinomic history of the diploporitans is, however, less trivial than it seems. Presuming a unidirectional 

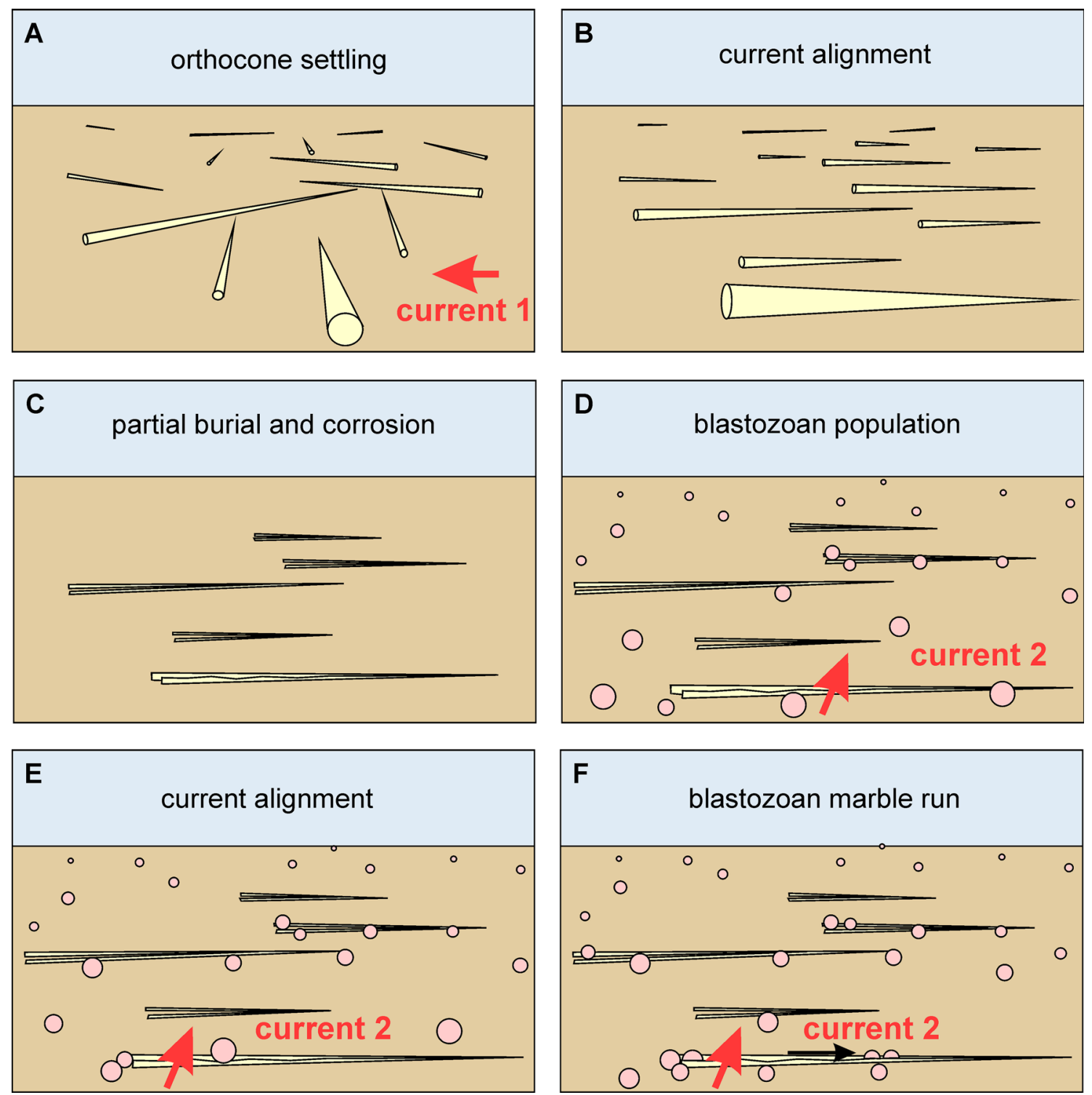

Fig. 3 Cartoon explaining the sorting of the diploporitans inside the orthoconic cephalopod conch or siphuncle. Alternatively, the current can be replaced by wave action and sloshing

current, the apex of the current-aligned orthocone likely pointed initially roughly in the direction of current, i.e. in the direction from where the diploporitan thecae probably arrived from. With its conical shape, the sides of the conch would have directed the diploporitans around rather than into the conch. There are a few scenarios to explain how the thecae came to rest in the conch:

1. It was wave action that aligned the conch or siphuncle perpendicularly to the current direction. Consequently, the diploporitans came from the long sides and not from the apical side.

2. The cephalopod conch edge was embedded more or less exactly to the sediment surface level; the conch or siphuncle wall did not form an obstacle preventing the diploporitans from entering the half conch.

3. Current direction changed after the cephalopod conch was embedded in the sediment; subsequently, the diploporitans rolled in from the sides or from the apertural side until they reached the spot where theca diameter corresponds to the inner cephalopod conch diameter in a sort of diploporitan-marble run. Those with a much larger or much smaller diameter were more easily washed out of the conch or siphuncle, because smaller diploporitans had more freedom to move and the larger diploporitans exposed larger surfaces outside the cephalopod shell remains. 
As mentioned by Lindskog and Eriksson (2017: p. 177), the sediments of the Täljsten formed in the intertidal to deep subtidal. Hence, wave action at least temporarily influenced the sediment surface, thus rendering scenario 1 possible. A combination of the processes 2 and 3 is a plausible explanation for the longitudinal size sorting of the diploporitans (for a graphic reconstruction of the processes, see Fig. 3), but of course, a combination of these processes cannot be ruled out.

Although we are not aware of similar cases of taphonomic arrangement, the taphonomic feature described herein can be compared with conch telescoping, a feature known specifically from slender orthoconic shells of dacryoconarids and cephalopods (e.g. Miller and Youngquist 1949; Bogolepova and Gubanov 1999). Telescoping was studied by Hladil et al. (2014: p. 376) employing an experimental approach. They found that "With sloshing, a high production of irreversibly telescoped cones was present in clear water and at driving frequencies comparable to the upper limits known for sea waves." It is conceivable that a sloshing process washed the diploporitans in and out of the orthoconic conch where only those stayed that assumed a stable position due to the strongly limited clearance.

\section{Conclusions}

We describe a specimen, where remains of an orthoconic cephalopod (probably an endocerid) of $332 \mathrm{~mm}$ length were filled with a chain of diploporitan thecae. This cephalopod fossil was probably aligned by either a current or wave action. It was apparently exposed to seawater for a prolonged time, which permitted corrosion to remove the exposed upper half of the conch or siphuncular tube, while the other half rested in the sediment. The remaining shell walls formed no obstacle for diploporitan thecae that rolled over the sediment, transported by currents or waves. There are two explanations for the dense packing and the nearly perfect fit of the diploporitans (Sphaeronites) to the half cephalopod conch: Either, the diploporitans entered the half orthocone and rolled on until they reached the point where the thecal diameter was equal to the inner diameter of the cephalopod conch or mild wave action caused a sloshing that removed those thecae from the conch that did not fit well into it. Once inside the conch, the diploporitans rolled on in the conch, thereby became size-sorted and ultimately reached a stable position, giving the specimen the superficial look of an actinocerid siphuncle.

Acknowledgements This contribution is dedicated to the great connoisseur of echinoderms Hans Hess. He is remembered as a very friendly colleague who produced many excellent publications of timeless value. We thank the Swiss National Science Foundation for funding our research (Project Number 200020_132870). We appreciate the careful work of Elise Nardin (Montpellier) and Johnny Waters (Boone, North Carolina) who thoroughly reviewed our manuscript and thereby helped to improve it.

\section{References}

Balashov, E. G. (1968). Endoceratoids from the Ordovician of the USSR (p. 276). Leningrad: Isdatelstvo Leningradskogo Universiteta. [In Russian]

Becker, D. A. (1978). Stem abscission in tumbleweeds of the Chenopodiaceae: Kochia. American Journal of Botany, 65, 375-383. https://doi.org/10.2307/2442692.

Bogolepova, O. K., \& Gubanov, A. P. (1999). Silurian cephalopod limestone biofacies from eastern Siberia. In F. Olóriz \& F. J. Rodríguez-Tovar (Eds.), Advancing research on living and fossil cephalopods (pp. 493-503). New York: Springer.

Calner, M., Ahlberg, P., Lehnert, O., \& Erlström, M. (Eds.) (2013). The Lower Palaeozoic of southern Sweden and the Oslo Region, Norway. Field Guide for the 3rd Annual Meeting of the IGCP project 591. SGU, 133, $96 \mathrm{p}$.

Eriksson, M. E., Lindskog, A., Calner, M., Mellgren, J. I. S., Bergström, S. M., \& Schmitz, B. (2012). Biotic dynamics and carbonate microfacies of the conspicuous Darriwilian (Middle Ordovician) 'Täljsten' interval, south-central Sweden. Palaeogeography, Palaeoclimatology, Palaeoecology, 367, 89-103.

Flower, R. H. (1955). Status of endoceroid classification. Journal of Palaeontology, 29, 329-371.

Fraas, E. (1887). Über ein Ophiuren-Vorkommen bei Crailsheim. Neues Jahrbuch für Mineralogie, Geologie und Paläontologie, 1888(1), 170-172.

Ganong, W. F. (1921). A textbook of botany for colleges (p. 359). London: MacMillan Co.

Grahn, Y. (1986). Orthocone nautiloid orientations in Arenig Llanvirn limestones of Öland, Sweden. Geologiska Föreningens $i$ Stockholm Förhandlingar, 108, 321-330.

Hladil, J., Simcik, M., Ruzicka, M. C., Kulaviak, L., \& Lisy, P. (2014). Hydrodynamic experiments on dacryoconarid shell telescoping. Lethaia, 47, 376-396.

Klug, C. (1992). Bemerkenswerte Stielglieder von Encrinus liliiformis. Fossilien, 5, 305-308.

Kröger, B. (2012). The "Vaginaten": the dominant cephalopods of the Baltoscandian Mid Ordovician endocerid limestone. $G F F$, 134, 115-132.

Kröger, B., \& Rasmussen, J. A. (2014). Middle Ordovician cephalopod biofacies and palaeoenvironments of Baltoscandia. Lethaia, 47, 275-295.

Kröger, B., \& Zhang, Y.-B. (2009). Pulsed cephalopod diversification during the Ordovician. Palaeogeography, Palaeoclimatology, Palaeoecology, 273, 174-183.

Lindskog, A., \& Eriksson, M. E. (2017). Megascopic processes reflected in the microscopic realm: sedimentary and biotic dynamics of the Middle Ordovician "orthoceratite limestone" at Kinnekulle, Sweden. GFF, 139, 163-183.

Maeda, H., \& Seilacher, A. (1996). Ammonoid taphonomy. In N. H. Landman, K. Tanabe, \& R. A. Davis (Eds.), Ammonoid paleobiology. Topics in geobiology (pp. 543-578). New York: Plenum Press.

Miller, A. K., \& Youngquist, W. (1949). The maquoketa coquina of cephalopods. Journal of Paleontology, 23, 199-204.

Neugebauer, J. (1978). Experimentelle Karbonatzementation: syntaxialer Calcit auf Echinodermen. Neues Jahrbuch für Geologie und Paläontologie, Montashefte, 9, 545-555. 
Neugebauer, J. (1979a). Fossil-Diagenese in der Schreibkreide: Echinodermen. Clausthaler Geologische Abhandlungen, 30, 198-229.

Neugebauer, J. (1979b). Drei Probleme der Echinodermendiagenese: Innere Zementation, Mikroporenbildung und der Übergang von Magnesiumcalcit $\mathrm{zu}$ Calcit. Geologische Rundschau, 68, 856-875.

Paul, C. R. C., \& Bockelie, J. F. (1983). Evolution and functional morphology of the cystoid Sphaeronites in Britain and Scandinavia. Palaeontology, 26, 687-734.

Regnell, G. (1960). The lower Palaeozoic echinoderm faunas of the British Isles and Balto-Scandia. Palaeontology, 2, 179-191.

Rothpletz, A. (1909). Über die Einbettung der Ammoniten in den Solnhofener Schichten. Königlich Bayerische Akademie der Wissenschaften, Abh., 24(2), 311-337.
Seilacher, A. (1963). Umlagerung und Rolltransport von Cephalopoden-Gehäusen. Neues Jahrbuch für Geologie und Paläontologie, Montashefte, 1963, 593-615.

Seilacher, A. (1971). Preservational history of ceratite shells. Palaeontology, 14, 16-21.

Vollbrecht, A. (2015). Exkursion Südost-Schweden Fieldtrip guidebook (p. 142). Göttingen: Freunde der Geowissenschaften der Universität Göttingen.

Walker, K. R., Jernigan, D. G., \& Weber, L. J. (1999). Petrographic criteria for the recognition of marine, syntaxial overgrowths, and their distribution in geologic time. Carbonates and Evaporates, 5, 141-151.

Wendt, J. (1995). Shell directions as a tool in palaeocurrent analysis. Sedimentary Geology, 95, 161-186. 